\title{
Land, Liberation and Compromise in Southern Africa
}

\author{
LSE Ideas
}

\section{By Chris Alden and Ward Anseeuw}

On the eve of the crisis in Zimbabwe, one that was to inexorably pull its neighbours into a regional reconsideration of the politics of land, a workshop was held in November 1999 in Windhoek, Namibia. The delegates, all members of the regional non-governmental network, Mwelekeo wa NGO or Mwengo, had come together to assess the regrettable inaction surrounding the land situation in their respective countries. In his opening remarks Uhuru Dempers pointed out that the liberation struggle in all the countries in Southern Africa had been inspired by the colonial dispossession of land. Despite this, he went on to say, land reform remained an area of struggle for all the countries. He hoped that the legacy of a common history and on-going initiatives in the area of land reform and redistribution would inspire Southern African NGOs to review their local circumstances and collaborate in future on land policy across the region

Within three months of the meeting, the regional quietude that so disturbed participants had been expelled by events in Zimbabwe. A 'fast track' land reform programme characterised by violent occupation of white commercial farm land by purported 'war veterans', overturned the unequal distribution of agricultural holdings that had been a part of the country's political economy for ninety years. NGO land activists in Namibia and South Africa, though disturbed by the violence that accompanied reform, generally welcomed developments in Zimbabwe as providing fresh impetus to their own local campaigns. Moreover, Robert Mugabe's revival of anti-imperialist rhetoric not heard since the era of liberation struggles shook the complacency of elite accumulation and seemed to promise a return to the revolutionary politics of the past. It was only as the Zimbabwean situation lurched from political controversy to economic free fall that the certainties that were expressed at the workshop began to fracture into a variety of regional responses.

For a very different corner of the region, white commercial farmers living in Zimbabwe, Namibia and South Africa watched events unfold in Zimbabwe with growing trepidation and public disquiet. From having once held a position of privilege under minority rule, these farming communities had endured uncertainties of the transition to a black government and had largely accommodated themselves to the new circumstances, even learning to prosper under a government dominated by their once implacable foes. Responded the rising crescendo of racial rhetoric and violence in Zimbabwe over land, the white commercial farmers' associations in all three ex-settler states issued an unprecedented joint statement in June 2000.

Due to the political past of most of the southern Africa countries, land restitution and land redistribution are imperatives for political, social and economic stability...Unfortunately, the result of failure with land reform cannot be ring-fenced to the country concerned, but its effects will be felt in the region.

(Cited in Ben Cousins, 'The Zimbabwe Crisis in its Wider Context: the politics of land, democracy and development in Southern Africa', in Amanda Hammar et al, eds., Zimbabwe's Unfinished Business: rethinking land, state and nation in the context of crisis (Harare: Weaver Press 2003), p. 263)

The former liberation movements who governed Namibia and South Africa, caught off-guard by the farm occupations and electoral violence in Zimbabwe, struggled to come up with a response to the Zimbabwean crisis that did not compromise their established political interests in office. Recognising their own vulnerability on agrarian reform, which they had promoted as a key tenet in their liberation struggle but largely neglected once in power, and worried the land issue could inspire disgruntled trade unionists and opposition parties, these governments found themselves embracing contrary policies: simultaneously defending property rights enshrined in their constitutions, acknowledging the imperatives of land reform across the region, placating international opinion, all the while honouring the regional principle of solidarity in their interactions with Zimbabwe. Within Namibia and South Africa's leading political parties, trade unions and amongst local NGOs, divisions began to appear which pitted democracy and human rights advocates against those arguing for a more thorough-going commitment to land reform by the government. For traditional leaders and their communities, the raising of the land issue brought with it the possibility of relief from their dire political and economic circumstances. By way of contrast, neighbouring Botswana and Mozambique - seemingly immune to the pressures being experienced by the two ex-settler states - reacted more forthrightly to the Zimbabwean crisis with authorities in Gaborone openly critical Mugabe while those in Maputo inviting white farmers to settle in their territory. And, from outside the region, the international community looked to the self-appointed beacon of democracy in the region, South Africa, to take a lead in criticising events in Zimbabwe and found to its surprise that it was tepid critic of the Zimbabwean government and its policies at best.

What happened to Zimbabwe, the model for Namibia and South Africa land reform programmes and a shining example of democratically inspired reconciliation between black and white? How did the land issue and its reform, which had once 
seemed if not resolved, certainly manageable with careful planning and sufficient good will, spill over into a blood bath of racial epithets and political violence? What effect did it have on shaping the dimensions of the land question in neighbouring states and, at the same time, fomenting solidarity with the Zimbabwe regime across Southern Africa? And what accounts for the differing responses by other states in the region, namely Botswana and Mozambique, with close economic ties to the neighbouring ex-settler states?

This book is an attempt to understand the origins of a crisis which started in Zimbabwe and why it has had such a profound impact on land and democratic politics in the Southern African region. It provides a framework for understanding the volatility inherent in the politics of land and, with that, the political structure of post-independent states in the Southern African region. The intimate links between the established political economy of settler colonialism, transition to democracy and the concurrent fashioning of a liberal constitutional regime, all of which held tremendously important implications for attempts to embark on agrarian reform, are part of the reason that the Zimbabwean crisis impacted so fundamentally on regional politics. The power of narratives in Southern Africa - drawn from the settler state era, the liberation struggle itself and implicit in neo-liberal policies pursue after independence - to shape preferences and perspectives amongst elites, social groups and the wider population is the other compelling source for the unexpected impact of the Zimbabwean crisis.

In order to meet the demands of such a study, the authors have embraced a comparative methodology which takes as its unit of analysis the Southern African regional political economy and its three dominant former settler states. It uses primary and secondary sources culled from Zimbabwe, South Africa and Namibia in order to understand the individual dynamics at work within each country as well as the cross-border engagement and effects these produced to weave together a comprehensive portrayal of the impact of the Zimbabwe crisis. As such, the responses of 'non-settler' and 'former settler' states, e.g. Mozambique and Botswana, were also analysed and serve as 'controls' regarding the formation and implementation of domestic policies on land and foreign policies in reaction to the Zimbabwean crisis. This assumption that a comparative approach rooted simultaneously in the particulars of each ex-settler state but framed within a broader region context is the correct basis for interpreting the actions and reactions at both the highest levels of policy as well as the responses of individuals and communities at ground level has guided the research throughout. Adopting this approach has underscored the centrality of narratives as a crucial conceptual device for explaining the conduct of political actors in relation to societies and the constraints (albeit at times self-imposed) experienced by them in addressing the problems of land within the liberalconstitutional states which they inherited in the transition to democracy.

Chris Alden is Lecturer in International Relations at the LSE

Ward Anseeuw is a research fellow at the Agricultural Research Centre for International Development (CIRAD), University of Pretoria, South Africa 